\title{
Martin Litchfield West
}

\section{(1937-2015)}

\section{Almut Fries}

In the late 1950s a gifted Classics undergraduate at Oxford was advised by E. R. Dodds, then Regius Professor of Greek, that he should turn his attention to prose works rather than poetry on the ground that little remained to be done there in the field of textual studies. Fortunately, the young man did not follow this no doubt honest and well-intentioned recommendation - for his name was Martin West.

This is one of the many anecdotes that circulate in Oxford about Martin West, whom I knew for nearly fifteen years and whose friendship I enjoyed for the last eight or so. The story is true - he himself recounted it, with characteristic self-irony, in his acceptance speech for the 2000 Balzan Prize (reprinted in Hesperos (2007), the Festschrift for his $70^{\text {th }}$ birthday) - but even if it were not, it is a good one because it encapsulates the scholarly personality of the man who long before his sudden death, on 13 July 2015, had become the world's foremost expert on early Greek poetry and its manifold connections in space and time. Never subject to changing intellectual fashions or afraid of challenging established doctrines (or of being challenged himself), Martin pursued his chosen path to the point of leaving a legacy which easily proves Dodds' opinion wrong and which few, if any, can ever hope to emulate.

Born in Hampton, Middlesex, on 23 September 1937, Martin went to St. Paul's School in London, still one of the leading independent schools for boys in Britain, before he came up to Balliol College Oxford to read Classics in 1955. Classical education in those days, both at school and initially at university, largely consisted of translation from and into Greek and Latin, prose and verse. It was this rigorous training, combined with supreme talent (even 'genius' would not be too grand a word), that provided the basis for his extraordinary feeling for language and style.

In Oxford he soon came to attend the legendary text-based seminars which Eduard Fraenkel had introduced on the German model. Taught by Wilamowitz and Leo, among others, Fraenkel not only impressed his students with his immense learning and love of ancient literature, but also led them to understand the essence of classical philology (in the continental sense). Throughout his life Martin saw himself as standing in this tradition - a portrait of Wilamowitz hung above his desk at home, and he often returned to 
pre-20 ${ }^{\text {th }}$-century scholarly literature for useful information or to resurrect a clever conjecture - yet almost from the beginning he also went far beyond the conventional boundaries of Altertumswissenschaft. Fraenkel's seminars proved life-changing for him in another respect: it was there that he met his wife, Stephanie, a distinguished Hellenist herself, who is affectionately mentioned in the prefaces to several of his books and to whom he dedicated his last one (The Making of the Odyssey, Oxford 2014) in gratitude for a lifetime of support.

Martin's attachment to German scholarship was strengthened in 1960 during a summer spent in Erlangen with Reinhold Merkelbach, who was so impressed with his visiting student that not much later they began to collaborate on a new edition of the Hesiodic fragments, which appeared in 1967. At Erlangen he was also befriended by Walter Burkert and Rudolf Kassel. The latter was important in his own way, but Merkelbach and Burkert were already interested in Near Eastern and Egyptian influences on Greek literature and culture, and their openness towards this line of inquiry had an enduring effect. Martin's doctoral thesis, which was supervised by Hugh Lloyd-Jones and examined by Kenneth Dover and Denys Page, resulted in the publication of his first book, an edition with introduction and commentary of Hesiod's Theogony (1966). Both this volume and its later counterpart on Hesiod's Works and Days (1978) abound with fundamental insights into the relationship between the Greek poems and Mesopotamian, Ugaritic, Phoenician, Hebrew and HurroHittite narrative and myth, in addition to everything one would expect of a traditional commentary. Nineteen years after Works and Days, and twenty-six after Early Greek Philosophy and the Orient (1971), Martin published what many would consider to be his greatest individual achievement - The East Face of Helicon. West Asiatic Elements in Greek Poetry and Myth (1997), a monumental compendium of Near Eastern echoes in early Greek literature, for which he learnt several oriental languages in order to be able to read the relevant texts in the original. It is the starting point for any further research in the field.

But Martin did not stop there. In 2007 a similar volume, exploring an even more ancient heritage, saw the light of day: Indo-European Poetry and Myth. Again he "furnished [himself] with a working knowledge of some of the relevant languages" ('Preface', v), to the point that a new translation of the Hymns of Zoroaster and a treatise on Old Avestan Syntax and Stylistics appeared in 2010 and 2011 respectively. A recent Hittite reading class in Oxford benefited greatly from his presence (as did many Comparative Philology graduate seminars over the years), and when one evening it had fallen to him to preside over dinner at his college, All Souls, he replaced the customary Latin grace with one of his own composition - in Vedic Sanskrit - which came as such a 
surprise that even the resident specialist in Indian religions did not recognise the language before it was over.

Martin's total academic output amounts to thirty-five books (editions, commentaries, translations and monographs) and more than 450 articles and reviews, ninety-three of which were re-published in three volumes of Selected Papers (Hellenica: Selected Papers on Greek Literature and Thought, Oxford 2011-2013); plus his new Teubner edition of the Odyssey, and several articles that have appeared or will do so posthumously. As Robert Parker, Wykeham Professor of Ancient History in Oxford, observed in his memorial address on 24 October 2015, "if we consider the whole field of Greek poetry down to the death of Aeschylus minus a single genre, lyric, once the text of the Odyssey is published, the whole of Greek poetry of those centuries will be available in an edition by Martin; and authoritative comment by Martin is available on all that ocean of poetry except the Homeric Hymns. Lyric is missed out only because it was already well served, but Martin also made innumerable contributions in that field". Add to this a delightful Aris \& Phillips commentary on Euripides' Orestes (the fastest ever produced, according to the series editor, Christopher Collard), standard manuals on textual criticism (1973) and Greek metre $(1982,1987)$, an extensive study of ancient Greek music (1992), an edition of the extant Greek musical fragments (2001, with Egert Pöhlmann of Erlangen) and a comparatively slender volume on Orphic poetry (1983), which somehow makes these murky waters look clearer than usual. What unites this enormous oeuvre is a mind that combined artistic sensitivity with a brilliant sense of formal logic (at school Martin also excelled in mathematics). What made it possible is a matter for speculation: self-discipline, ruthless efficiency and a staggering capacity for concentration.

Martin's career was correspondingly stellar. After being the first holder of the Woodhouse Junior Research Fellowship at St. John's College Oxford (1960-1963) he became Fellow and Praelector in Classics at University College Oxford (1963-1974) and Professor of Greek at Bedford (later Royal Holloway and Bedford) College London (1974-1991), before he returned to Oxford as a Senior Research Fellow at All Souls College (Emeritus Fellow 2004, Honorary Fellow 2014). In 1973 he was elected Fellow of the British Academy (the second-youngest in its history), and a host of other distinctions followed: honorary doctorates and membership of foreign academies, honorary fellowships in all his Oxford colleges, the Runciman Award (1998, for The East Face of Helicon), the International Balzan Prize (2000, ten years after his friend Walter Burkert) and the British Academy's Kenyon Medal for Classical Studies (2002). But all these were surpassed by his appointment, in the 2014 New Year's Honours List, to the Order of Merit (OM), which lies in the gift 
of the British monarch and is restricted to twenty-four members at any one time. It moved him deeply, but like the other accolades he wore it lightly, with the modesty that was part of his character. To everybody's amusement at the reception with which the Oxford Classics Faculty marked the occasion, the celebratory cake that had been ordered for him sported a textual error in its inscription. Martin deftly excised the obnoxious passage - with a cake knife.

Personally, Martin was a quiet man. But behind his extreme reserve, which together with his scholarly eminence and a considerable talent for put-down remarks could make him seem a forbidding figure, lay an uncommonly kind and generous spirit and a splendidly zany sense of humour. He lectured to undergraduate classics societies and other student bodies as well as audiences of distinguished academics, was always ready to comment on the work of friends and colleagues all over the world (sometimes without being explicitly asked), and gladly gave advice, encouragement and spare books to young scholars (provided they met his rigorous standards). While praise and criticism were dispensed with equal honesty, the former was much the rarer and could come in a form that required translation ("Now what you told me today was all quite sensible"). But precisely for that reason one could be genuinely proud of having received it. It made a difference.

Martin's verbal wit will be evident to anyone who leafs through the obiter dicta at the end of the third volume of his Hellenica. Examples are easily multiplied, both from his prefaces and the texts themselves; they adorn his crisp and lucid prose like so many hidden gems ("I would have been more ashamed of the opposite fault" was his response to anticipated charges of excessive brevity in the preface to his Studies in Greek Elegy and Iambus (1974)). Journal articles were not safe either, as one can see from titles like "Two Lunatic Notes" (Zeitschrift für Papyrologie und Epigraphik 50 (1983): 46), which proposes emendations for two mythical passages to do with the moon and is anything but 'lunatic' in the more common metaphorical sense of the word. Astronomy was one of Martin's pastime interests since his teenage years, and he typically carried it to a high level; his first three publications were in the Journal of the British Astronomical Association, and he regularly returned to the subject in academic writings. He also left behind several published and unpublished jeux d'esprit, including two versions of Lewis Carroll's Jabberwocky, one in Homeric and one in Nonnian hexameters (Greece \& Rome $2^{\text {nd }}$ series 11 (1964): 185-187) and, somewhat more seriously, a charming account of how the Iliad was composed. Written in German as a conference paper, it adopts the style of an ancient Homeric biography (featuring a rhapsode called Meli, short for Meliglōssos) and parodies the notion that one can know exactly how the 
poem came into being (in C. Ulf - R. Rollinger (eds.), Lag Troja in Kilikien? Der aktuelle Streit um Homers Ilias, Darmstadt 2011, 329-340).

Away from the page, older colleagues also report a certain propensity for practical jokes, such as placing a large artificial spider on his shoulder during a Classics dinner at University College to see how his fellow-banqueters would react. More recently Martin delighted in wearing one of the most elaborate and colourful academic robes - that which came with his honorary doctorate from the University of Cyprus - at the annual garden party following Encaenia (the ceremony at which Oxford's honorary degrees are awarded). Finally, he was an enthusiastic Lord Mallard, the holder of an unofficial post at All Souls College, whose main function is to lead the twice-yearly singing of a raucous song that commemorates the supposed appearance of a gigantic mallard duck when the college was being built. And Martin would not have been Martin had he not marked the recurrence of the great centennial Mallard Feast and Procession in 2001 with a comprehensive academic study of the legend.

"I am a part of all that I have met", says Tennyson's Ulysses in the section of the poem that was selected for reading at Martin's memorial service. It was an excellent choice. No one who has ever encountered Martin West, the scholar or the man, is likely to forget the experience. Like the subjects and creators of his beloved early Greek poetry, he has earned himself imperishable fame by ensuring that they are better understood by posterity.

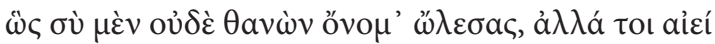

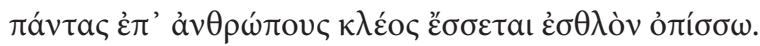

So not even in death did you lose your name, but always you shall have noble fame among all men in times to come.

Hom. Od. 24.93-4 (adapted) ${ }^{1}$

\section{References}

Finglass, Patrick J.; Collard, Christopher; Richardson, Nicholas J. (eds.) 2007. Hesperos: Studies in Ancient Greek Poetry Presented to M. L. West on his Seventieth Birthday. Oxford: Oxford University Press.

\footnotetext{
1 I am grateful to Stephanie West and Robert Parker for providing support and background information, to Christopher Collard and Simon Hornblower for much good advice, and to the editors of Studia Metrica et Poetica for giving me the opportunity to write this memoir.
} 
Merkelbach, Reinhold; West, Martin L. (eds.) 1967. Fragmenta Hesiodea. Oxford: Oxford University Press.

Pöhlmann, Egert; West, Martin L. 2001. Documents of Ancient Greek Music. Oxford: Oxford University Press.

West, Martin L. 1960. Anaxagoras and the Meteorite of 467 B.C. In: Journal of the British Astronomical Association 70: 368-369.

West, Martin L. 1961. An Ancient Reference to the Quadrantids. In: Journal of the British Astronomical Association 71: 206.

West, Martin L. 1961. Alleged Apparitions of Halley's Comet in the Eighteenth Century B.C. and Earlier. In: Journal of the British Astronomical Association 71: 324-326.

West, Martin L. 1964. Two versions of Jabberwocky. Greece \& Rome $2^{\text {nd }}$ series 11: 185-187.

West, Martin L. (ed.) 1966. Hesiod, Theogony. Oxford: Oxford University Press.

West, Martin L. 1971. Early Greek Philosophy and the Orient. Oxford: Oxford University Press.

West, Martin L. 1973. Textual Criticism and Editorial Technique Applicable to Greek and Latin Texts. Stuttgart: Teubner.

West, Martin L. 1974. Studies in Greek Elegy and Iambus. Berlin and New York: Walter De Gruyter.

West, Martin L. (ed.) 1978. Hesiod, Works and Days. Oxford: Oxford University Press.

West, Martin L. 1982. Greek Metre. Oxford: Oxford University Press.

West, Martin L. 1983. The Orphic Poems. Oxford: Oxford University Press.

West, Martin L. 1983. Two Lunatic Notes. In: Zeitschrift für Papyrologie und Epigraphik 50: 46 .

West, Martin L. (ed.) 1987. Euripides, Orestes. Warminster: Aris \& Phillips.

West, Martin L. 1987. Introduction to Greek Metre. Oxford: Oxford University Press.

West, Martin L. 1992. Ancient Greek Music. Oxford: Oxford University Press

West, Martin L. 1997. The East Face of Helicon: West Asiatic Elements in Greek Poetry and Myth. Oxford: Oxford University Press.

West, Martin L. 2001. The All Souls Mallard: Song, Procession, and Legend. Oxford: All Souls College. 
West, Martin L. 2007. Indo-European Poetry and Myth. Oxford: Oxford University Press.

West, Martin L. 2010. The Hymns of Zoroaster: A New Translation of the Most Ancient Sacred Texts of Iran. London: I. B. Tauris.

West, Martin L. 2011. Old Avestan Syntax and Stylistics: With an Edition of the Texts. Berlin and Boston: Walter De Gruyter.

West, Martin L. 2011. Die Entstehung der Ilias: Ein Roman. In: Ulf, Christoph, Rollinger, Robert (eds.), Lag Troja in Kilikien? Der aktuelle Streit um Homers Ilias. Darmstadt: Wissenschaftliche Buchgesellschaft, 329-340.

West, Martin L. 2011-2013. Hellenica: Selected Papers on Greek Literature and Thought, 3 vols. Oxford: Oxford University Press.

West, Martin L. 2014. The Making of the Odyssey. Oxford: Oxford University Press. 